\title{
Rancang Bangun Turbin untuk PLTMH di Jalan Bintara Sungai Duren Kecamatan Jambi Luar Kota Kabupaten Muaro Jambi
}

\author{
Ahmad Murtadho', Venny Yusiana ${ }^{2}$ \\ ${ }^{1,2}$ Teknik Listrik, Fakultas Teknik, Universitas Batanghari \\ Correspondence Email: tadhoa64@gmail.com; vyusaki@yahoo.com
}

\begin{abstract}
Abstrak. Penelitian ini dilakukan untuk mengetahui karakteristik turbin air yang digunakan pada pembangkit listrik tenaga mikro hidro (PLTMH) dengan mengamati pengaruh variasi tinggi jatuh air terhadap putaran yang dihasilkan turbin dan variasi transmisi putaran dengan diameter pulley yang berbeda untuk menghasilkan putaran yang digunakan untuk memutar generator .Hasil penelitian menunjukkan bahwa tinggi jatuh air aliran air berpengaruh pada putaran yang dihasilkan turbin, dan memvariasikan sistem transmisi pulley juga dapat memaksimalkan putaran pada generator.
\end{abstract}

Kata Kunci: Turbin, Pulley; Tinggi jatuh air

Abstract. This research was conducted to determine the characteristics of water turbine used on micro hydro Power Plant (PLTMH) by observing the influence of high variation falling water to the turbine generated round and rotation transmission variation with different pulley diameter to generate the rotation used for rotating the generator. The results showed that high water-falling water streams have an effect on the resulting rounds of turbines, and varying the pulley transmission system can also maximize the rotation on the generator.

Keywords: turbine, Pulley; High Falling water

\section{PENDAHULUAN}

Energi listrik merupakan energi yang tidak bisa lepas dari kehidupan masyarakat. Kegiatan manusia dengan listrik menjadi lebih lancar, penyebaran informasi menjadi lebih cepat dan mudah, serta dapat meningkatkan kesejahteraan manusia. Kebutuhan akan energi listrik merupakan kebutuhan yang tidak dapat ditawar lagi untuk kehidupan yang layak bagi setiap orang pada zaman sekarang ini. Pemanfaatan sumber energy listrik bisa di dapat di sekitar lingkungan penduduk, misalnya dengan pemanfaatan pembangkit.[1]

Pembangkit listrik tenaga air skala mikro merupakan salah satu sumber energi yang dapat dikembangkan secara luas dengan menggunakan kapasitas air yang tidak terlalu besar. Pembangkit tenaga listrik sebagian besar dilakukan dangan cara memutar generator sinkron sehingga didapat tenaga listrik. [2]

Dari sinilah penulis membuat sebuah pembangkit listrik sederhana yang dapat digunakan untuk kebutuhan listrik rumah tangga.

Sistem mikrohidro telah dikembangkan di beberapa negara untuk memenuhi kebutuhan listrik di daerah pedalaman antara lain Peltric Set di Nepal, Columbian Alternator System diKolombia, dan Pico Power Pack di Amerika. Ketiga sistem tersebut menggunakan turbin impuls sebagai penggerak.[3]

Kualitas aliran jet yang dihasilkan oleh nosel dapat mempengaruhi kinerja turbin. Penelitian tentang hal ini dilakukan oleh Kvicinsky dkk (2002), dimana analisis aliran jet pada permukaan sudu turbin dilakukan secara numerik maupun eksperimen. Hasil penelitian menunjukkan bahwa kualitas aliran jet berpengaruh pada distribusi tekanan dan medan kecepatan pada permukaan sudu sehingga daya dan efisiensi turbin akan berubah.[3]

Staubli dan Hauser (2004) memvisualisasikan aliran jet keluar nosel berpenampang lingkaran dalam berbagai bentuk divergensi dengan cara memodifikasi dalam berbagai sudut jarum governor pada nosel. Divergensi jet ternyata berpengaruh terhadap karakteristik jet pada permukaan sudu. Hasil modifikasi menunjukkan peningkatan kinerja turbin, yang berarti modifikasi geometri nosel dapat menambah kualitas aliran jet yang dihasilkan nosel.[3]

\section{Turbin}

Terdapat dua jenis turbin air (PLTA DAN PLTMH) yaitu:

\section{Turbin Impulse}

Turbin impulse umumnya menggunakan kecepatan dari air untuk menggerakkan runner dan dilepaskan pada tekanan atmosfir.Aliran air menyemprot setiap piringan pada runner.Tidak ada bagian yang menghisap dibawah turbin dan air mengalir kebawah rumah turbin setelah mengenai runner. Turbin impulse umumnya cocok untuk yang memiliki head tinggi dan volume air rendah salah satu jenis turbin ini adalah turbin cross flow.

\section{Turbin Reaksi}

Turbin reksi menghasilkan daya dari kobinasi tekanan dan pergerakan air.Runner di letakkan langsung pada aliran arus.turbin reaksi biasanya digunakan untuk 
lokasi PLTA/PLTMH yang memiliki head yang lebih rendah dan debit yang lebih besar dibandingkan dengan turbin impluse.

Type Turbin ini dipengaruhi oleh "head" atau tinggi dari air terhadap turbin dan debit atau volume air di lokasi Pembangkit. Faktor lain yang mempengaruhi adalah efisiensi dan biaya.
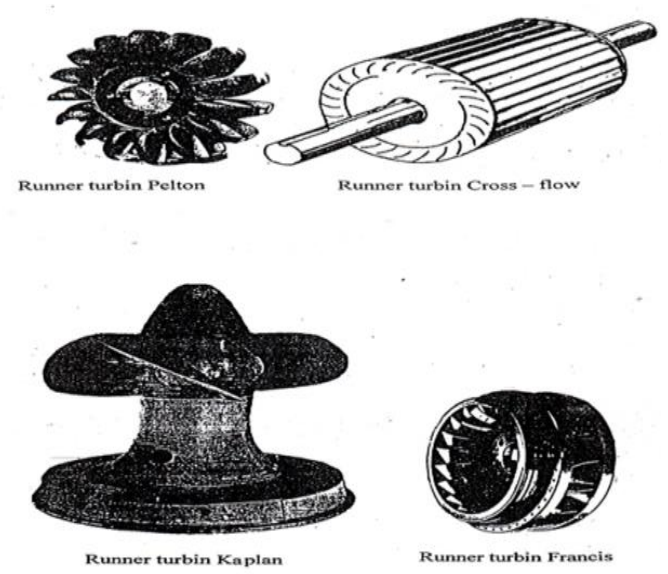

Gambar 1. Macam Macam Turbin

\section{Turbin Crossflow}

Turbin crossflow merupakan turbin impuls dengan tipe aliran radial.Awal pengembangan turbin crossflow (banki turbine) didasarkan pada teori Banki yang mempatenkan konsepnya sekitar tahun 1920. Turbin crossflow sekarang ini sudah jarang dipakai dan digantikan oleh turbin-turbin yang lebih modern seperti turbin Pelton, Francis atau pun Kaplan. Tetapi bagaimanapun juga, turbin crossflow mempunyai keunggulan tersendiri yang tidak dimiliki turbin jenis lain.

Turbin crossflow dapat dioperasikan pada debit air sebesar 20 liter/dt hingga 10.000 liter/dt dan head antara $1 \mathrm{~m}$ sampai $200 \mathrm{~m}$. Turbin crossflow menggunakan nosel persegi panjang yang lebarnya sesuai dengan lebar runner. Pancaran air masuk turbin dan mengenai sudu sehingga terjadi konversi energi kinetik menjadi energi mekanik.Air mengalir keluar membentur sudu dan memberikan energinya (lebih rendah dibanding saat masuk) kemudian meninggalkan turbin.Runner turbin dibuat dari beberapa sudu yang dipasang pada sepasang piringan parallel.

Turbin crossflow adalah radial, turbin bertekanan kecil dengan injeksi tangensial dari putaran kipas dengan poros horisontal.Aliran air mengalir melalui pintu masuk pipa, dan diatur oleh baling-baling pemacu dan masuk ke putaran kipas turbin.Setelah air melewati putaran kipas turbin, air berada pada putaran kipas yang berlawanan, sehingga memberikan efisiensi tambahan. Energi mekanik fluida yang akan diberikan ke turbin setelah dikurangi gesekan dan rugi-rugi lainnya yang dikenal dengan Water House Power (WHP).[4]

\section{Keuntungan ke ekonomian}

Dengan meningkatnya minat masyarakat akan kelestarian lingkungan dalam upaya mencari sumber daya alam yang dapat digunakan seperti memproduksi energi listrik dari sumber energi terbarukan. Sayangnya, penggunaan power hydro terbatas oleh faktor-faktor yang sangat signifikan sebagai berikut ini : tingginya biaya instalasi, termasuk desain dan perencanaan, dimensi, serta produk dari mesin yang dibutuhkan.

Oleh karena itu penulis membuat Turbin crossflow dari komponen standar yang dikonfigurasikan sesuai dengan kebutuhan pelanggan - yaitu diperhitungkan secara menyeluruh potensi dari air dan Ketinggian (head) dilokasi ditempat tertentu.

Turbin crossflow memiliki purna jual yang panjang dan bebas perawatan.Selama pengoperasian, tidak diperlukan suku cadang yang mahal atau kompleks, maupun dapat di perbaiki langsung dilapangan. Keuntungan tertentu turbin crossflow adalah dapat digunakan dalam sistem air bersih gravitasi, bahkan di saluran yang sangat panjang, ataupun tidak menyebabkan dampak yang tidak diinginkan secara hidrolik dan dengan demikian tidak mempengaruhi kualitas air minum selama pengoperasian.

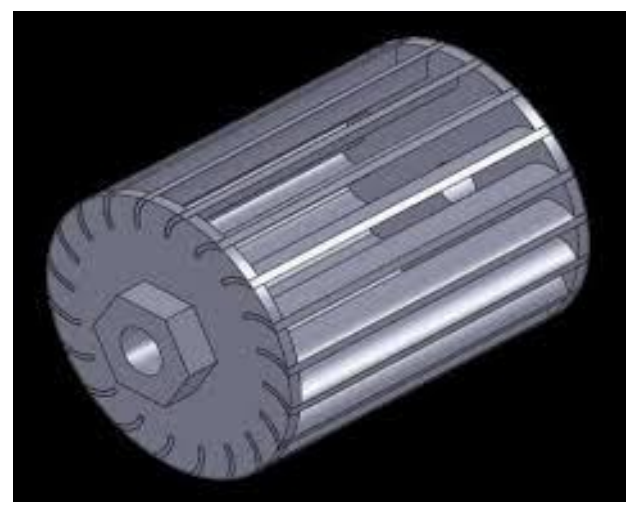

Gambar 2. Turbin crossflow

\section{Prinsip Turbin Crossflow}

Turbin Crossflow adalah radial, turbin bertekanan kecil dengan injeksi tangensial dari putaran kipas dengan poros horisontal.Turbin ini digolongkan sebagai turbin berkecepatan rendah.Aliran air mengalir melalui pintu masuk pipa, dan diatur oleh baling-baling pemacu dan masuk ke putaran kipas turbin. Setelah air melewati putaran kipas turbin, air berada pada putaran kipas yang berlawanan, sehingga memberikan efisiensi tambahan.Akhirnya, air mengalir.

Pada prakteknya, aliran air pada putaran kipas memberikan efek pembersihan sendiri. Setiap kotoran yang terdorong diantara putaran kipas akan masuk bersama air yang juga ditarik keluar oleh gaya sentrifugal. Setelah setengah putaran dari kipas, air mengambil kotoran yang keluar dan menyembur keluar.

Jika aliran air berubah - ubah, maka turbin Crossflow dirancang dengan dua sel. Pembagian standar 
dari sel masuk adalah 1:2.Sel sempit memproses aliran air kecil dan sel lebar memproses aliran deras.Kedua sel bersama-sama memproses aliran penuh.Dengan pembagian ini, aliran air yang digunakan adalah 100 sampai $17 \%$ pada efisiensi optimal.Dengan demikian turbin Crossflow dapat digunakan pada aliran sungai yang sangat bervariasi, bahkan mencapai efisiensi $80 \%$. [5]

\section{Cara kerja turbin Crossflow}

Adapun cara kerja turbin Crossflow ini adalah Tahap pertama yang dilakukan adalah mengarahkan air mengalir melalui pipa menuju ke nozzle penyemprot. Dan dari nozzle lalu air disemprotkan ke sudu turbin yang menyebabkan turbin serta As turbin berputar sehingg kita bisa mengukur prestasi turbin.

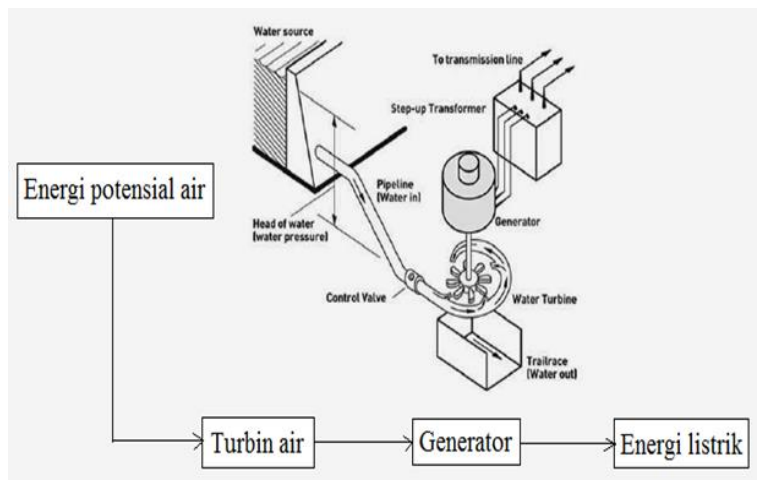

Gambar 3. Prinsip Kerja PLTMH

\section{METODE}

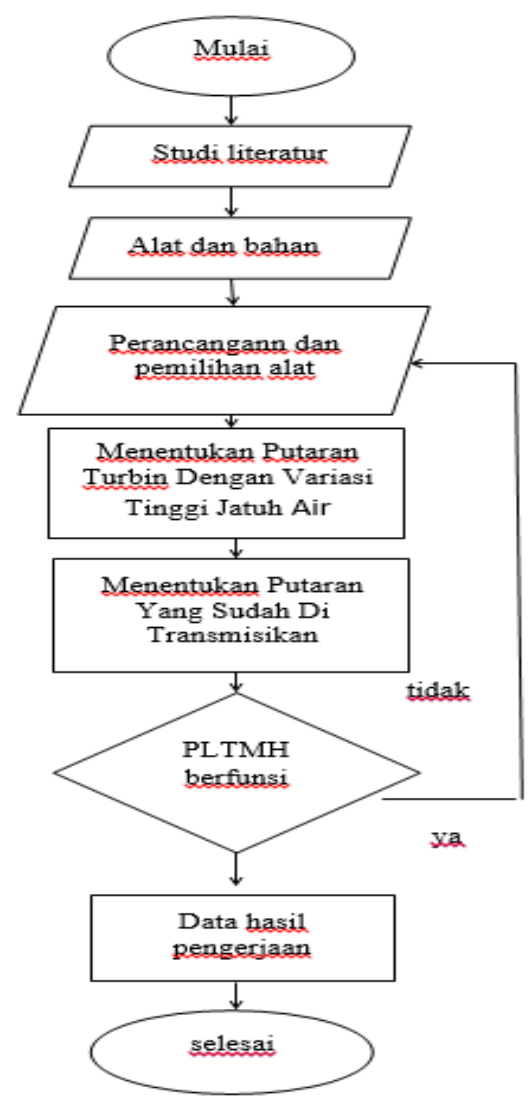

Gambar 4. Diagram Alur

\section{Alat dan Bahan}

Setelah mencari referensi, barulah menyiapkan alat alat apa saja yang di butuhkan, utuk mempermudah pekerjaan dan bahan bahan apa saja yang dibutuhkan

Tabel 1. Jenis Alat/Bahan

\begin{tabular}{|c|c|c|}
\hline No & Alat/Bahan & Jumlah \\
\hline 1 & Tachometer & 1 \\
\hline 2 & Gerinda & 1 \\
\hline 3 & Mesin las & 1 \\
\hline 4 & Busur & 1 \\
\hline 5 & Bor & 1 \\
\hline 6 & Mistar & 1 \\
\hline 7 & $\mathrm{~V}$ belt & 1 \\
\hline 8 & Pulley & 2 \\
\hline 9 & Plat & 1 \\
\hline 10 & Fiber & 1 \\
\hline 11 & Pipa pvc & 1 \\
\hline 12 & Baut & 4 \\
\hline 13 & Batang ass & 1 \\
\hline 14 & Klahar duduk & 2 \\
\hline 15 & Besi siku & 2 \\
\hline
\end{tabular}

\section{Perancangan dan Pemilihan Alat}

Perancanga dimulai dengan mendata terlebih dahulu alat dan bahan yang sudah ada lalu kemudian dilakukan perhitungan terhadap skala utama turbin Cross Flow jika sudah berhasil dan sesuai dengan standar yang direncanakan kemudian dilakukan survey ketersedian dipasaran untuk menyesuaikan kebutuhan dari hasil perhitungan yang di dapatkan setelah itu dilanjutankan pada pembuatan desain turbin Cross Flow nya namun bila tidak sesuai kembali lagi pada perancangan awal. Yang mana perancangan dan pemilihan alat yang digunakan :

1. Turbin Cross Flow yang sudah di rangkai

2. Aki untuk membangkitkan listrik yang dapat menghasilkan tegangan dan arus

3. Lampu sebagai beban

4. Pipa PVC 3 inci

5. Multimeter yang digunakan untuk mengatur arus dan tegangan yang dihasilkan oleh turbin

6. Alat ukur rpm (tachometer)

7. Generator

8. Pulley

9. Batang Ass

10.Klahar duduk

\section{Menentukan Daya Generator}

Untuk memilih kemampuan generator dalam menghasilkan energy listrik sesuaikan dengan perhitungan daya 250 watt.Dari kecepatan nilai rata turbin kita bisa menentukan daya yang bisa dihasilkan pada generator.Dan juga kita harus membuat turbin berputar slalu aktif dan daya yang dihasilkan oleh Generator.Generator juga selalu stabil. 
Ahmad Murtadho dan Venny Yusiana, Rancang Bangun Turbin untuk PLTMH di Jalan Bintara Sungai Duren Kecamatan Jambi Luar Kota Kabupaten Muaro Jambi

\section{Data Hasil Pengujian}

Data hasil pengujian dapat diambil ketika alat bekerja dengan benar sesuai dengan apa yang telah di rencanakan

\section{HASIL DAN PEMBAHASAN}

Dalam penelitian ini turbin yang dirancang adalah turbin jenis crossflow, adapun bagian-bagian atau komponen untuk membuatnya seperti sudu, lingkaran diameter turbin bagian kanan dan kiri sudu terbuat dari plat besi dengan tebal $1 \mathrm{~mm}$ dan besi as.

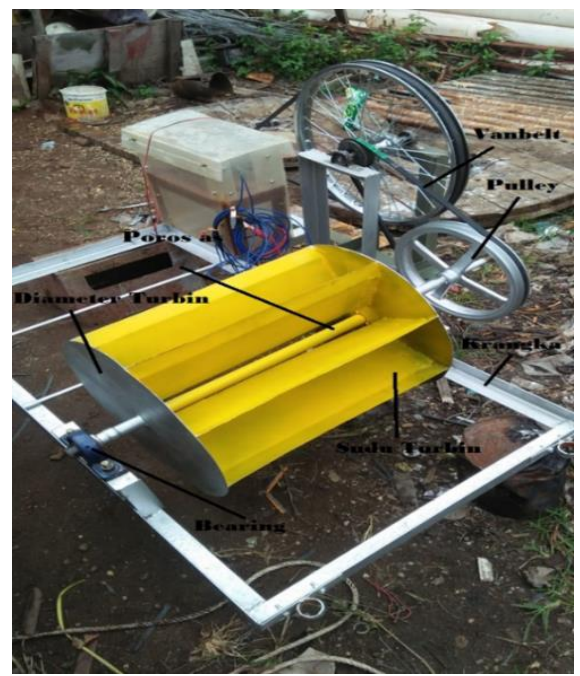

Gambar 5. Rancangan Turbin

Keterangan:

1. Diameter lingkaran turbin $40 \mathrm{~cm}$

2. Jari - jari lingkaran turbin $20 \mathrm{~cm}$

3. Jumlah sudu 8 buah

4. Jarak antar sudu $15 \mathrm{~cm}$

5. Lebar sudu $45 \mathrm{~cm}$

6. Tinggi sudu $30 \mathrm{~cm}$

\section{Pengujian Sistem Transmisi Pulley}

Untuk mendapatkan putaran yang lebih besar maka pada perancangan alat ini dilakukan dengan mentransmisi putaran dari putaran rendah ke putaran tinggi menggunakan pulley. Tabel 4.2 berikut menunjukkan berbagai ukuran pulley untuk mendapatkan putaran yang diinginkan

Tabel 2. Data Pengujian Pulley

\begin{tabular}{ccc}
\hline No & Ukuran Pulley (inchi) & $\begin{array}{c}\text { Putaran Yang Dihasilkan } \\
\text { Generator (Rpm) }\end{array}$ \\
\hline 1 & 6 & $400 \mathrm{~s} / \mathrm{d} 500$ \\
2 & 9 & $600 \mathrm{~s} / \mathrm{d} 700$ \\
3 & 11 & $700 \mathrm{~s} / \mathrm{d} 800$ \\
\hline
\end{tabular}

Dari data diatas semakin besar ukuran pulley maka kecepatan putaran yang dihasilkan akan semakin tinggi. Untuk itu maka dalam rancangan ini digunakan pulley dengan diameter 11 inchi.

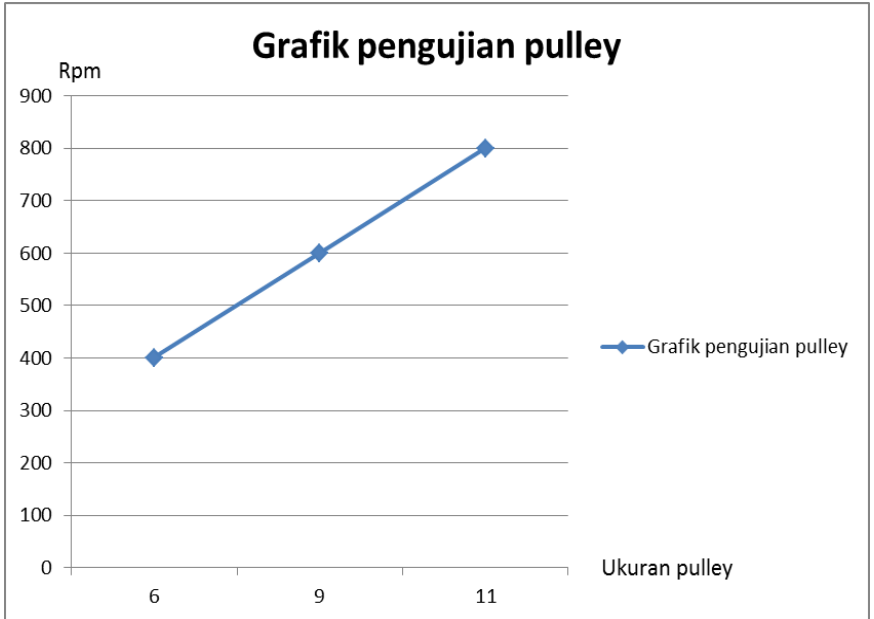

Gambar 6. Grafik Hubungan RPM Turbin Terhadap Pulley

\section{Pengujian Tinggi Jatuh Air}

Dalam penentuan jatuh air (head) dilakukan pengujian dengan variasi jatuh air (head) seperti yang terlihat pada tabel berikut:

Tabel 3. Data Pengujian Jatuh Air

\begin{tabular}{lccc}
\hline No & Head & Rpm Poros & Rpm Hasil Transmisi \\
\hline 1 & $20 \mathrm{~cm}$ & 82 & 540 \\
2 & $34 \mathrm{~cm}$ & 88 & 642 \\
3 & $51 \mathrm{~cm}$ & 102 & 790 \\
\hline
\end{tabular}

Dari hasil memvariasikan ketinggian jatuh air/head menggunakan pipa dengan diameter 2 inch diketahui bahwa semakin jauh atau tinggi jatuh air maka putaran yang di hasilkan turbin akan semakin kencang pula, jadi disini yang akan di gunakan adalah titik jatuh yang terjauh dan tepat di titik jatuh yang diinginkan agar mendapat putaran yang maksimal.

\section{SIMPULAN}

1. Jika debit air semakin tinggi maka putaran yang dihasilkan juga akan semakin tinggi.

2. Hubungan debit dengan tekanan menunjukkan bahwa semakin tinggi debit air maka akan semakin tinggi tekanannya dan jika debit air menurun maka tekanannya juga akan menurun.

\section{DAFTAR PUSTAKA}

[1] Jack, Fritz.1984, 'Small and Mini Hydropower System, 'McGraw-Hill, 'New York,.

[2] Ir. Djiteng Marsudi.'2005.'Pembangkitan Energi Listrik, 'Balai Penerbit Humas ISTN Bhumi. 'Serengseng Indah.

[3] Muhamad Saleh Simamora, Program Studi Teknik Mesin,Fakultas Teknik Universitas Pasir Pengaraian.

[4] Kevinmuhamad, '2017/09/22 ',jornal PLTMH Pembangkit Listrik Tenaga Mikro Hidro,'S Surabaya

[5] Haimerl, L.A.'(1960). 'The Cross Flow Turbine. 'Jerman Barat 